\title{
India and the USA: A Comparison through the Lens of Model IT Curricula
}

\author{
Jonathan Ezer \\ London School of Economics, London, UK \\ Jonathan@salon-voltaire.com \\ Executive Summary
}

This study compares two model curricula - one from India and one from the USA. These two countries have played a starring role in the development of information technology. Moreover, model curricula are useful tools for comparison of how different countries perceive and perpetuate ideas surrounding IT.

Firstly, it was found that the Indian curriculum is far more instrumental than the American curriculum. Emphasis was placed on business applications of technology, laying bare the desire to turn graduates into engineers. Chemistry, Physics, and Electronics were well represented in the Indian curriculum but not at all in the American curriculum, possibly reflecting an Indian preference for this type of "hard" epistemology. This indicates that American and Indian curriculum designers perceive IT somewhat differently, and this may have significant implications for the way technology is developed in these two countries.

Keywords: India, USA, Model IT Curriculum, Curriculum Analysis, IT Education

\section{Introduction}

The release of The Association of Computing Machinery (ACM) IT 2005 Model Curriculum presents an occasion to conduct some very interesting research. Many commentators have suggested that information technology is the "Great Globalizer", removing frontiers and connecting people in ways that were previously unimaginable (Castells, 2001; Eggleston, Jensen, \& Zeckhauser, 2002; Fukuyama, 1992). To perpetuate the drive for more integration, these commentators often argue that IT education should meet global standards.

Not everyone agrees. Particularly when referring to developing countries, some authors believe that the desire to bring Western knowledge with Western assumptions into markedly different cultures is at best naïve, and at worse patronizing (Avgerou \& Walsham 2000; Wade 2002). They argue that instead of tailoring education to global standards, IT education should address local needs.

Material published as part of this journal, either on-line or in print, is copyrighted by the publisher of the Journal of Information Technology Education. Permission to make digital or paper copy of part or all of these works for personal or classroom use is granted without fee provided that the copies are not made or distributed for profit or commercial advantage AND that copies 1) bear this notice in full and 2) give the full citation on the first page. It is permissible to abstract these works so long as credit is given. To copy in all other cases or to republish or to post on a server or to redistribute to lists requires specific permission and payment of a fee. Contact Editor@JITE.org to request redistribution permission.
This debate is particularly relevant for India. While India has a much heralded software outsourcing industry, the majority of its population live in poverty (Nicholson \& Sahay, 2001; World Bank, 2002). Writers on contemporary India often link societal tensions with a schizophrenic attitude to modernity (Lal, 2003). The All India Council for Technical Education (AICTE) is a statutory body in India 
that oversees all technical education. They publish model curricula for Information Technology similar to that published by the ACM.

This special issue of the Journal of IT Education - on the ACM IT 2005 model curriculum - presents a unique opportunity for interesting comparisons. This paper will compare the two model curricula mentioned above and reveal the similarities and differences in the way IT knowledge is interpreted and transmitted. In doing so, it will hopefully make some relevant observations regarding IT education in these two countries that have had such strong influence on the development of IT.

\section{Research Framework}

There is a significant body of literature that deals with IT curriculum, however the research tends to be prescriptive or normative. Many papers address the deficiency in many computer science (and related) courses, and discuss what ought to be taught, how curricula should be set up, and which programs best suit student needs (Barrett, Davis \& Leeper, 1985; Buckingham \& McFarlane, 2001; Reichgelt, Zhang \& Price, 2002).

Reffell and Whitworth (2002) have argued forcefully that most IT education is ineffective because it is too technical and not at all concerned with local contexts and real world problems. Other case study research seems to support this argument. In Brunei, IT education was too rationalized and modernistic for the country's rentier economy (Minnis, 2000). Likewise, in Papua New Guinea, the desire for a Western style IT education programme caused disruptive tensions between local and foreign academics (Kelegai \& Middleton, 2002). However, Neville (1998) argued that Malaysia's IT education programme was particularly successful because it was narrowly focused on a modernistic agenda. On a higher, more abstract level, some argue that computers are over-hyped, do not increase productivity, and so the need for them is overstated (Garnham, 2000). Others argue the opposite - that IT is now a fourth basic competence, equal in importance to reading, writing and arithmetic (Bohme, 2002).

At the heart of these debates is a fundamental disagreement about what it is that universities do. Some argue cogently that universities must first satisfy the needs of industry (Eggleston, 1994; Kohli \& Health, 2001; Liu \& Jiang, 2001; Roberts, 2000). Others who support this claim point out that the reason students go to university is primarily because they want good jobs (Dougherty, 1988), and argue that education should focus on achieving full employment (Saunders \& Machell, 2000). Yet some authors believe that universities are already too focused on employment and industry, which is detrimental to their teaching and research (Williams, 2000). A more idealistic school argues that rather than pander to industry, universities should help build pure knowledge, social capital and the capacity for critical thinking (Aronowitz \& Giroux, 1991; Conceicao, Gibson, Heitor, \& Sirlli, 2001; Freire, 1972; Giroux, 1983; Reffell \& Whitworth, 2002).

Banks (1994) characterized this as "The Great Debate", between "liberal" and "instrumental" education. For him, liberal education rests on a desire to harvest the intellect and develop a highly analytical and critical way of thinking. A liberal education sees the pursuit of knowledge as active and interconnected, not simply a recollection of facts. Liberal education tends to create a hierarchy of cerebral subjects, such as Latin, Physics and Mathematics that have a higher status. The risk of such a system is that schools become divorced from the world of work, and education loses any notion of immediate usefulness. On the other hand, instrumental education is based on the premise that education serves society. An emphasis is placed on the relevance and utility of education, where students are expected to apply their knowledge vocationally, contributing to the economy. The risk of such a system is that students are encouraged to simply meet some identified need, rather than think critically with the purpose of achieving some sort of personal or communal advancement. 
Of course, there is no pure dichotomy between liberal and instrumental education, but these categories are useful in understanding various education systems. These terms will be used extensively throughout this paper and so warrant the brief summary shown in Table 1.

\begin{tabular}{|c|c|}
\hline \multicolumn{2}{|c|}{ Table 1: Instrumental versus Liberal Education } \\
\hline Instrumental & Liberal \\
\hline Allow people to fill needs (jobs) in society & Harvest the Intellect \\
\hline Teach useful and relevant skills & Develop Critical Thinking \\
\hline e.g. Web Development, Marketing & e.g. Theory of Computation, Latin \\
\hline $\begin{array}{l}\text { Criticized for being dumbed-down, present- } \\
\text { oriented. }\end{array}$ & Criticized for being divorced from the real world \\
\hline
\end{tabular}

Adapted from (Banks 1994)

\section{The Field of Curriculum Studies}

While the prescriptive literature is directly related to the development of model IT curricula, other descriptive literature has a role to play as well. In the field of education, a sub-discipline has emerged known as curriculum studies. According to Geoff Whitty (1985), the study of curricula took on a new direction in the late 1960s and early 1970s. A leading academic in this field was Michael F. D. Young who related the

principles of selection and organization that underlie curricula to their institutional and interactional setting in schools and classrooms and to the wider social structure (Young 1971a as quoted in Whitty, 1985 p. 7).

Curriculum analysis is a useful way to study a particular phenomenon because curricula have the capacity to reveal institutionalized assumptions within a particular domain, and they are researchable. Curricula are manifested in documents that can be read and understood. Moreover, as many education scholars have suggested, they reflect values and forces within an education system. Curricula are "ideology in practice" (Coffey, 2001; Whitty, 1985) a mechanism to achieve cultural reproduction from one generation to the next. Curricula can also act as a reflection of power relationships within a society.

How a society selects, classifies, distributes, transmits and evaluates the educational knowledge it considers to be public reflects both the distribution of power and the principles of social control (Bernstein, 1971 p. 85).

Bernstein added elsewhere:

There is nothing intrinsic about how educational time is used, or the status of the various contents or the relation between the contents. I am emphasizing the social nature of the system of choices from which emerges a constellation called a curriculum (Bernstein, 1977 p.80).

Ivor F. Goodson $(1985 ; 1994 ; 1998)$ has developed wide-ranging works in the study of curriculum. He argued that curricula underpin assumptions about power relationships and institutional forces (Goodson, 1994). School subjects are not monolithic, but change and are re-negotiated. The debate over curricula can be interpreted as a conflict between subjects over status, resources and territory (Goodson, 1994). Thus, curriculum construction has such central significance, and the study of curricula can be particularly illuminating. Within curricula, patterns of resource allocation, legitimacy, and power relationships are all inscribed (Goodson, 1998). 
Finally, the study of curricula is intriguing because of the way it treats what we know as problematic in order that it becomes as object of inquiry (Young, 1971b).

\begin{abstract}
It is not surprising that treating knowledge in this way has excited more than a ripple of interest, particularly amongst philosophers of education, for the worthwhileness of particular educational activities can no longer be justified in absolute terms once the social basis of such justification is recognized. The apparent self-evident justification for education into particular forms of knowledge is laid bare as an ideological statement. The process through which particular curricula are institutionalized and justified becomes open to sociological examination ... We are forced into an often uncomfortable re-examination of the content and underlying assumptions of the curriculum at all levels (Gorbutt, 1972 p.7-8).
\end{abstract}

\title{
Methodology
}

Thus, this study will compare the model IT curricula from the ACM and the AICTE to reveal taken-for-granted epistemological assumptions. Unfortunately, the two documents were not written so that they may be easily compared. The AICTE curriculum outlines a detailed plan for implementation, while the ACM curriculum is more high-level, focusing more on defining the knowledge base and outlining some essential principles. One particular difficulty arises from the fact that the Indian (AICTE) curriculum explicitly states how many hours should be spent studying non-IT material such as business and marketing. The American (ACM) curriculum only expresses the need to gain familiarity with application domains.

It should also be noted that the mandates of these two organizations are different. The ACM is an association of professionals and practitioners focused on IT in the broader sense. The AICTE is a statutory government body overseeing all technical education.

Despite the difficulties, a comparison is possible. The curricula will be compared along two lines; first a comparison of what each considers the core knowledge base; Second, a comparison of the preamble text and the principles underpinning curricula construction.

The AICTE knowledge base is arranged by year and semester. Thus, the curriculum outlines not just the material to be studied, but also the course of study. By contrast, the ACM curriculum outlines the knowledge base in terms of categories of topics. To make the comparison possible, the courses listed in AICTE curriculum will be categorized into topics similar to that of the ACM curriculum.

One may criticize this approach sharply. Indeed, components of the knowledge base (from the ACM curriculum) are not necessarily the same thing as courses listed in a program of study. The author accepts this criticism, however without such adjustments, a comparison of the two curricula is impossible, and yet, as will be shown, such a comparison is very much worthwhile. The discussion continues with this limitation in mind.

\section{Comparison of Curricula}

\section{Comparison of the Knowledge Base}

Table 2 outlines the knowledge base from the ACM curriculum alongside the courses from the AICTE curriculum, categorized into topics. 
Table 2: Comparison of Model Curricula - By Hours

AICTE (India) Model Curriculum

\section{Information Technology}

Knowledge
Similarities
Information Technology
Fundamentals

Data Communication \& Networking

Platform Technologies

System Administration and

Maintenance

Information Management

Internet

Programming Fundamentals

(Systems)

Advanced Programming

Significant Differences

English Proficiency and Humanities

Business \& Marketing

Graphics

Mathematics

Mechanical Engineering

Chemistry

Thermodynamics

Physics

Electrical Engineering / Electronics

Simulation

Theory of Computation

Self Directed (Electives and Project Work)

Workshop Practice
ACM (USA) Model Curriculum

Information Technology

Knowledge Topic

hrs

hrs Knowledge Topic hrs

Information Technology

Fundamentals

Networking

20

Platform Technologies

System Administration and

Maintenance

Information Management

Web Systems and Technologies

Integrative Programming \&

Technologies

Information Assurance and Security

Human Computer Interaction

System Integration and Architecture

Social and Professional Issues

Note: The ACM curriculum expresses the need to familiarize students with various application domains including business; however it does not specify any quantitative or qualitative requirements.

Total Hours 270

Adapted from: (ACM and IEEE Computer Society 2005; AICTE 2000)

Immediately, it is worth taking note of the similarities. Both curricula offer fundamental courses in information technology, system development and the basics of operating systems and hardware architecture. Moreover, both curricula offer courses on web technologies and programming fundamentals (although these differ at lower levels of detail). 
Nevertheless, there are major differences in emphasis. The Indian curriculum puts the emphasis on Platform Technologies (operating systems, hardware architecture). By contrast, the American curriculum puts the emphasis on programming fundamentals. Comparing the rankings of knowledge topics (See Table 3.) generates some interesting observations.

\begin{tabular}{|c|c|c|c|}
\hline $\begin{array}{l}\text { AICTE (India) Model Curriculum } \\
\text { Information Technology }\end{array}$ & & $\begin{array}{c}\text { ACM (USA) Model Curriculum } \\
\text { Information Technology }\end{array}$ & \\
\hline Knowledge Topic & Rank & Knowledge Topic & Rank \\
\hline $\begin{array}{l}\text { Information Technology } \\
\text { Fundamentals }\end{array}$ & 4 & $\begin{array}{l}\text { Information Technology } \\
\text { Fundamentals }\end{array}$ & 3 \\
\hline Data Communication \& Networking & 5 & Networking & 6 \\
\hline Platform Technologies & 1 & Platform Technologies & 7 \\
\hline $\begin{array}{l}\text { System Administration and } \\
\text { Maintenance }\end{array}$ & 8 & $\begin{array}{l}\text { System Administration and } \\
\text { Maintenance }\end{array}$ & 8 \\
\hline Information Management & 2 & Information Management & 2 \\
\hline Internet & 7 & Web Systems and Technologies & 5 \\
\hline $\begin{array}{l}\text { Programming Fundamentals } \\
\text { (Systems) }\end{array}$ & 3 & Programming Fundamentals & 1 \\
\hline Advanced Programming & 6 & $\begin{array}{l}\text { Integrative Programming \& } \\
\text { Technologies }\end{array}$ & 4 \\
\hline
\end{tabular}

Adapted from: (ACM and IEEE Computer Society, 2005; AICTE, 2000)

The differences in rank between the knowledge topics are usually 2 or less, however there is 1 major exception: Platform technologies is ranked $1^{\text {st }}$ in the Indian curriculum and $7^{\text {th }}$ in the American curriculum. The reasons for these contrasts in emphasis become more clear where examining the significant differences between the curricula.

Significant indeed! The Indian curriculum gives major importance to hard engineering and science disciplines such as Chemistry, Physics, Mathematics, Electrical and Mechanical Engineering, even Thermodynamics, which together amount to 57 hours of instruction, more than any other category.

In addition, the Indian curriculum puts emphasis on Business and Marketing, which is treated only vaguely in the American curriculum, as an application domain of which students should gain familiarity. This is significant in light of the great debate mentioned above. It suggests that the Indian curriculum is more instrumental, focusing more directly on the current global economy, and the immediate usefulness of its graduates.

Finally, it should be noted that the Indian curriculum outlines 35 hours for various electives and project work. This may not be significant, as the ACM curriculum does not proscribe an exact course of study; rather, it simply outlines the core components of the body of knowledge.

While the total number of hours are nearly identical (281 - 270, a difference of 4\%), the American curriculum clearly outlines a course of study that delves deeper into the issues directly related to information technology, such as security, usability and other social issues. The Indian curriculum places a significant emphasis on "hard" engineering disciplines such as mechanical and electrical engineering. 
Some of the particular nuances of the Indian curriculum are interesting to consider. Physics is given 10 hours of instruction whereas Chemistry is only allocated 5 hours. The reasons for this are likely due to historical traditions, availability of materials, or biases in the academic profession. But they hint at other characteristics of the Indian curriculum. There may be more inertia in the Indian system due to a lack of resources, and old assumptions, such as the importance of Physics in the arena of IT, are difficult to question. Other possible explanations include an Indian preference for scientific epistemology. More research is required to test these propositions further.

\section{Comparison of Guiding Principles}

The preamble texts of model curricula are rarely interesting. Nevertheless, they can reveal certain underlying assumptions about the curriculum designers, or the institutional forces that influence their work. The preamble text from the AICTE curriculum reads:

The economic progress of a country is strongly linked with the quality of education. It is therefore, necessary for our technical education to undertake periodic review of the curriculum and subject content of the technical programmes to ensure that they are up to date not outmoded or obsolete and effectively fulfill the technological requirements of the country (AICTE, 2000, p.4).

This puts the rationale for updating the curriculum squarely on the desire for economic progress, and it is implied that no other reason is necessary. The preamble goes on to suggest that norms and standards of education should be set up "so as to educate the students with appropriate skills suitable for a rapidly changing industrial scenario" (AICTE, 2000).

The above passage also makes clear that what is meant by "appropriate skills" are skills that are "suitable for a rapidly changing industrial scenario. (emphasis added)." This passage further indicates a preference for an instrumental orientation, a preference that is again alluded to in the following passage.

... To make India's industries internationally competitive, the frontier technologies have to flow from the $\mathrm{R}$ and $\mathrm{D}$ institutions to the industries and also be continually infused in the engineering curriculum. Thus, it is pertinent that educational institutions, industries, and research institutions which are at the three vertices of a triangle should converge at some nucleus through coordinated research in both conventional and emerging fields catering to the need of the industry, which will be transferred to the industry and also amalgamated in the engineering curricula (AICTE, 2000, p.6) [emphasis added].

The preamble lists the following four objectives.

1. Greater emphasis on design oriented teaching, teaching of design methodologies, problem-solving approach.

2. Greater exposure to industrial and manufacturing processes.

3. Exclusion of outmoded technologies and inclusion of the new appropriate and emerging technologies.

4. Greater input of management education and professional communication skills. (AICTE 2000)

The explanation of point 2 is particularly revealing:

2. Exposure to practical field 
In the industrially advanced countries of the world, there exists a long tradition of close partnership between academic institutions and industry in promoting technical education and research. In our country, despite a growing awareness of the importance of forging linkages between universities and industry, the interaction between them is still rather limited. Although both sides realize that this gap needs to be bridged, most of the initiative towards such bridge-building have come from educational institutions, hitherto with little success. The result is that education has remained stagnant while industries have advanced. The curriculum must aim to provide to the student greater exposure of actual industrial processes. Students' projects should be related to actual problems identified with the help of practicing engineers. Greater stress should be laid on the practical training of engineering graduates and sandwich programmes should be encouraged wherever feasible (AICTE, 2000, p.7).

The implication seems to be that participants from industry are invited and encouraged into the formal curriculum development process, something that is highly contested at Western universities (Banks, 1994). The underlying assumption seems to be that this link is a necessary condition to become an advanced industrialized country.

The central point that needs to be stressed is that the assumption behind the AICTE curriculum is that students who follow the curriculum are to be molded into engineers crafted to suit the needs of Indian Industry. This helps explains why the preamble is so instrumental and why the rationale for updating the curriculum is for "economic growth". More importantly, it also partly explains why Physics, Chemistry and Thermodynamics are included in the IT curriculum in India. It is because of the unstated aim of producing competent engineers.

The preamble to the ACM curriculum is particularly noteworthy in contrast because it does not locate its raison d'etre in the need for economic growth. Section 1.4 outlining the broad goals of the program reads:

IT programs aim to provide IT graduates with the skills and knowledge to take on appropriate professional positions in Information Technology upon graduation and grow into leadership positions or pursue research or graduate studies in the field. Specifically, within five years of graduation a student must be able to:

1. Explain and apply appropriate information technologies and employ appropriate methodologies to help an individual or organization achieve its goals and objectives;

2. Manage the information technology resources of an individual or organization;

3. Anticipate the changing direction of information technology and evaluate and communicate the likely utility of new technologies to an individual or organization;

4. Understand and for some to contribute to the scientific, mathematical and theoretical foundations on which information technologies are built;

5. Live and work as a contributing, well-rounded member of society.

This preamble is also somewhat instrumental. The emphasis is still on making sure graduates are useful, not on classic knowledge or high levels of intellectual attainment. However, it would not be correct to say the two preambles are equally instrumental. The ACM curriculum explicitly states as an objective that some students will contribute to scientific and theoretical understanding. Moreover, the fifth point is significant. It is an explicit aim to develop well-rounded members of society. 


\section{Analysis}

The thrust of this analysis is not to criticize the Indian curriculum for its instrumental nature. Indeed, it may be the case that tailoring a curriculum in order to generate economic growth will bring more benefit than a more liberal education otherwise would. It is beyond the scope of this paper to make such value judgments on the merits of either curriculum. The following three points are worth observing:

1. The Indian curriculum is much more instrumental than the American curriculum. Business courses are prominent in the knowledge base and the preamble texts explicitly put forth the need for economic growth as the driving force of curriculum change. The curriculum is explicit that "Information Technology" graduates are to be molded as engineers.

2. The major significant difference between the curricula is the prominence of "hard" science and engineering courses in the Indian curriculum, courses that are completely absent in the American curricula. These include Chemistry, Physics, Electronics and Thermodynamics; courses that are only tangentially related (if at all) to Information Technology.

3. In lieu of the "hard" engineering courses, the American curriculum offers courses that delve deeper into technical issues and courses that deal with the social issues surrounding information technology.

As mentioned above, the debate about whether education should be focused on the current job market (instrumental) or intellectual attainment (liberal) is ongoing. Perhaps it is the case that as a developing country, with millions of people in poverty, India is wise to target their education to the needs of their economy. By contrast, some may argue that America has the luxury to offer a more liberal education. This point should not be belabored because the American curriculum is also instrumental, only beside the Indian curriculum does it appear liberal.

To some extent, the American curriculum is instrumental, but expressed differently. Whereas the Indian curriculum is notably more technical, the American curriculum is far more social. Factors such as assurance, security, and human-computer interaction, are prominent in the American curriculum but non-existent in the Indian. The American curriculum pays noted attention to the social issues surrounding Information Technology. Given the AICTE's desire to turn their graduates into engineers, there is no evidence to suggest that social issues will be as prominent in the Indian curriculum in the near future.

The current emphasis on technology is well-entrenched in the Indian education system and so India will likely remain technology-focused for at least the foreseeable future. If one believes that Information Systems are social systems, then one might surmise that the future applications of technology, the ones with the greatest impact on humanity will not be solely technical. The findings of this study suggest that India is not well-placed to develop these socio-technical applications. Indian businesses may continue to excel in technology. However, the country may face difficulties in developing innovations that incorporate both technological and social aspects.

\section{Conclusions and Contributions}

Much has been written about the digital divide and the potential for Information Technology to deliver millions out of poverty. In this ongoing discussion, India is often presented as the exemplar country, and many others explicitly aim to copy the Indian example (Adelakun 2005).

Curricula are often seen as a snapshot of the current state of knowledge. Therefore, the release of the 2005 Model IT Curriculum from the ACM provides a unique opportunity to compare snapshots. The image taken from ACM is significantly different to that from the AICTE, and com- 
parison yields some interesting observations about the way information technology is perceived in the two countries.

This brief paper attempts to make four modest contributions to the study of information technology education:

1. As argued by many in the field of education, the methodology of curriculum analysis is very useful in teasing out power relationships, patterns of legitimacy and unquestioned assumptions in a particular phenomenon of interest. This study supports their view, and suggests that curriculum analysis should be employed to greater effect in the future, as we strive to understand how knowledge about information technology is perceived, interpreted and transmitted.

2. The Indian curriculum was found to be more instrumental than the American curricula. Emphasis was placed on business applications of technology, laying bare the desire to turn graduates into engineers.

3. Chemistry, Physics, Mathematics and Electronics were well represented in the Indian curriculum but discussed only in passing (if at all) in the American curriculum, possibly reflecting an Indian preference for this type of "hard" epistemology.

4. Security, Usability and other social issues were well represented in the American curriculum but not at all in the Indian curriculum, possibly reflecting an American preference for this type of "soft" epistemology.

Finally, this study can make some useful suggestions for future research linking information technology to curriculum studies. There is an ongoing debate about whether IT can help developing countries. While there are many diverse views, education always plays a strong role. Education shapes the way people think about technology and in turn, how it is to be used. Studying IT education in developing countries, particularly through the lens of curricula, can be worthwhile in understanding the potential impact of IT.

In the case of India, the observations made here lead to some obvious suggestions for future research. Clearly, a wider survey of Indian curricula would be beneficial to affirm or refute these findings. Moreover, it would be worthwhile to try and understand the institutional forces that impact IT education, for this will help us understand the various roles that IT can play in various contexts.

While many commentators have argued that IT is the "Great Globalizer", IT education has not converged to some worldwide standard. There are some obvious similarities across various curricula, but also some conspicuous differences as well. A greater understanding of these similarities and differences will help us understand the different ways that IT is perceived and the longrun potential impact of IT. Such an understanding will also reveal new ideas for IT education and for future model IT curricula.

\section{References}

ACM and IEEE Computer Society (2005). The ACM IT 2005 curriculum model. Retrieved 10 January 2005, from: http://campus.acm.org/public/comments/it 2005.pdf

Adelakun, O. (2005). Offshore IT outsourcing to emerging economies - Analysis of readiness vs. attractiveness. IFIP WG 9.4, Abuja, Nigeria. May 24-26, 2005.

AICTE (2000). Model curriculum for undergraduate programme in B.E./B. tech in computer science and engineering. New Delhi: All India Council for Technical Education.

Aronowitz, S. \& Giroux, H. A. (1991). Postmodern education. USA: University of Minnesota Press. 
Avgerou, C. \& Walsham, G. (Eds.). (2000). Information technology in context: Studies from the perspective of developing countries. UK: Ashgate.

Banks, F. (1994). Vocational education, general education and the place of technology. In F. Banks (Ed.), Teaching Technology. UK: Routledge.

Barrett, R. A., Davis, B. C., \& Leeper, R. (1985). A developmental computing course for computer technology majors. ACM SIGCSE Bulletin, 17(1), 152 - 154.

Bernstein, B. (1971). On the classification and framing of educational knowledge. In M. F. D. Young (Ed.), Knowledge and control. London: Collier-Macmillan.

Bernstein, B. (1977). Class and pedagogies - Visible and invisible. In B. Bernstein (Ed.), Class, codes and control. London: Routledge \& Kegan Paul.

Bohme, G. (2002). A fourth basic cultural competence. The Canadian Journal of Sociology, 27 (2), 199 210.

Buckingham, D. \& McFarlane, A. (2001). A digitally driven curriculum?@School Project, UK.

Castells, M. (2001). The internet galaxy: Reflections on internet, business and society. Oxford: Oxford University Press.

Coffey, A. (2001). Education and social change. USA: Open University Press.

Conceicao, P., Gibson, D. V., Heitor, M. V. \& Sirlli, G. (2001). Beyond the digital economy: A perspective on innovation for the learning society. Technological Forecasting and Social Change, 67(2), 115-142.

Dougherty, K. (1988). Educational policy-making and the relative autonomy of the state. Sociological Forum, 3 (3), 400-432.

Eggleston, J. (1994). What is design and technology education? In F. Banks (Ed.), Teaching Technology. UK: Routledge.

Eggleston, K., Jensen, R. \& Zeckhauser, R. (2002).Information and communication technologies, markets and economic development. In G. Kirkman, \& M. Chowdhury (Eds.), The global information technology report: Readiness for the networked world. UK: Oxford University Press.

Freire, P. (1972). Pedagogy of the oppressed. UK: Sheed and Ward.

Fukuyama, F. (1992). The end of history and the last man. UK: Hamish Hamilton.

Garnham, N. (2000). 'Information society' as theory of ideology. Information, Communication \& Society, 3 (2), 139-152.

Giroux, H. A. (1983). Theory \& resistance in education: A pedagogy for the opposition. USA: Bergin \& Garvey.

Goodson, I. F. (1985). Social histories of the secondary curriculum. London: The Falmer Press.

Goodson, I. F. (1994). Studying curriculum. UK: Open University Press.

Goodson, I. F. (1998). The making of curriculum. London: The Falmer Press.

Gorbutt, D. (1972). The new sociology of education. Education for Teaching, 89, 3-11.

Kelegai, L. \& Middleton, M. (2002). Information technology education in Papua New Guinea: Cultural, economic and political influences. Journal of Information Technology Education, 1 (1), 11-23. Retreived from http://jite.org/documents/Vol1/v1n1p011-024.pdf

Kohli, R. \& Health, T. (2001). Industry - academia interaction: Key to IT relevance. Communication of the Association for Information Systems, 6 (15), 1-4.

Lal, V. (2003). Of cricket, Guiness and Gandhi. India: Seagull Books.

Liu, H. \& Jiang, Y. (2001). Technology transfer from higher education institutions to industry in China: Nature and implications. Technovation, 21(3), 175-188. 
Minnis, J. R. (2000). Caught between tradition and modernity: Technical-vocational education in Brunei Darussalam. International Journal of Educational Development, 20(3), 247-259.

Neville, W. (1998). Restructuring tertiary education in Malaysia: The nature and implication of policy changes. Higher Education Policy, 11(4), 257-279.

Nicholson, B. \& Sahay, S. (2001). Some political and culture issues in the globalisation of software development: Case experience from Britain and India. Information and Organization, 11, 25-43.

Reffell, P. \& Whitworth, A. (2002). Information fluency: Critically examining IT education. New Library World, 103, 427-435.

Reichgelt, H., Zhang, A., \& Price, B. (2002). Designing an information technology curriculum: The Georgia Southern University experience. Journal of Information Technology Education, 1 (4), 213-222. Retrieved from http://jite.org/documents/Vol1/v1n4p213-221.pdf

Roberts, E. (2000). Computing education and the information technology workforce. ACM SIGCSE Bulletin, $32(2), 83-90$.

Saunders, M. \& Machell, J. (2000). Understanding emerging trends in higher education curricula and work connections. Higher Education Policy, 13(3), 287-302.

Wade, R. (2002). Bridging the digital divide: New route to development or new form of dependency? Global Governance, 8 (4), 443-466.

Whitty, G. (1985). Sociology and school knowledge. UK: Methuen.

Williams, K. (2000). Beyond the needs of industry: The liberal dimension of a technological education. Pedagogy, Culture and Society, 8 (1), 85-92.

World Bank. (2002). 2002 world development indicators. Retrieved July 22, 2003, from http://www.worldbank.org/data/wdi2002/pdfs/table\%202-6.pdf.

Young, M. F. D. (1971a). An approach to the study of curricula as socially organised knowledge. In M. F. D. Young (Ed.), Knowledge and control. London: Collier-Macmillan.

Young, M. F. D. (Ed.). (1971b). Knowledge and control. London: Collier-Macmillan

\section{Biography}

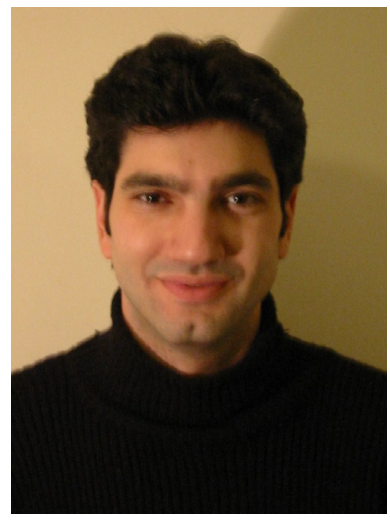

Jonathan Ezer specializes in the study of IT education, particularly in developing countries. He is interested in the way values and attitudes towards technology are inscribed through education, and revealed in curricula. 